\title{
Capsular Typing of Staphylococcus aureus Isolated from Raw Milk Samples using Duplex Polymerase Chain Reaction
}

\author{
A. Khan $^{1 *}$, R. Sharma ${ }^{1}$, R. Grover ${ }^{1}$ and M. Rizwan ${ }^{2}$ \\ ${ }^{1}$ Department of Biotechnology, Mahatma Jyoti Rao Phoole University, \\ Jaipur, Rajasthan, India \\ ${ }^{2}$ Multi-Disciplinary Research Unit, S.P. Medical College, Bikaner, Rajasthan, India \\ *Corresponding author
}

\begin{tabular}{l} 
K e y w o r d s \\
$\begin{array}{l}\text { Staphylococcus } \\
\text { aureus, Milk, cap5, } \\
\text { cap8 }\end{array}$ \\
\hline Article Info \\
$\begin{array}{l}\text { Accepted: } \\
15 \text { October } 2020 \\
\text { Available Online: } \\
10 \text { November } 2020\end{array}$ \\
\hline
\end{tabular}

\section{A B S T R A C T}

The present investigation was designed to determine the frequency of capsular polysaccharide genes (cap5 \& cap8) in Staphylococcus aureus strains isolated from raw milk samples of various regions of Jaipur, the capital city of Rajasthan state of India. In this study presence of $S$. aureus and cap5and cap 8 gene was evaluated by Polymerase Chain Reaction. A sum of 59 strains of $S$. aureus (confirmed by $23 \mathrm{~S}$ rRNA amplification) were selected and screened for the presence of capsular genes. PCR amplification of the gene segment encoding cap5 and cap 8 gene yielded product size of 361 and $173 \mathrm{bp}$, respectively. In the present study total $54.24 \%$ strains were found to carry cap 5 gene whereascap 8 gene was found with $27.12 \%$ prevalence. Presence of both genes was found is $10.17 \%$ strains. Maximum prevalence $(66.76 \%)$ of cap5 gene was present in the strains of Amer and Bagru regions while lowest prevalence $(37.50 \%)$ was found in the strains of Durgapuraregion of Jaipur city. Further, prevalence of cap 8 gene was maximum $(42.86 \%)$ found in strains of Sodala area which is surprisingly as similar as cap5 gene and was lowest in strains of Amer area (11.11\%). 25\% of the strains of Durgapura area were not typable. This study revealed that presence of cap5 gene was higher than cap 8 gene and also provides an idea that infection of $S$. aureus may pose a potential risk to human health and these result may support the future strategies and actions related to milk safety programs.

\section{Introduction}

Milk is a great medium for the growth of many microorganisms and microbial contamination in milk can be largely happen from three fundamental sources viz. inside the udder, outside of the udder and through the surface of milk dealing equipments. The prevalent unhygienic conditions, poor commercialization of dairy sector and improper handling practices favors the entrance of these undesirable and infectious microorganisms into milk and affects the overall nutritional and market value of the product. As evidence from previous investigations, presence of such pathogenic bacteria poses serious health hazards to human and animal's health (Soomro et al., 2003). 
Staphylococcus aureus is an essential pathogen of nosocominal contaminations and it is liable for wide scope of human illnesses including skin disease, bone infection, food contamination, endocarditic, toxic shock syndrome etc. Remembering bovine mastitis for domesticated animals $S$. aureus is likewise the third most revealed reason for food borne diseases on the earth (Normanno et al., 2005).

Different PCR based identification techniques were produced for $S$. aureus identification but most of them were not found satisfactorily or trustworthy to distinguish total strains of Staphylococcus aureus. Afterward, Straub et al.(1999) built up a Polymerase Chain Reaction (PCR) framework which depended on single primer pair focused against $23 \mathrm{~S}$ rRNA based species targeted primer, permitting targeted identification of total strains of species. The aimed sequence $23 \mathrm{~S}$ rRNA was picked on the grounds that it satisfied the necessity of phylogenetic marker having most reliability. This technique is presently being utilized broadly by numerous researchers all through the world for genotypic identification and authorization of Staphylococcus aureus among different type of contaminations (Khichar et al., 2014).

Capsular polysaccharide enhances the bacterial virulence by rendering the bacteria resistant to phagocytosis. Although 11 capsular polysaccharide serotypes have been recognized in Staphylococcus aureus isolates, only types 5 and 8 are common in Staphylococcus aureus isolated from human and bovine infections.

The majority of Staphylococcus aureus strains isolated from bovine mastitis is encapsulated and the distribution of capsular serotypes among Staphylococcus aureus isolates from bovine mastitis from different countries shows great variability. Hence this study was designed to characterize cap5 and cap 8 genes in $S$. aureus isolates from raw milk samples of different regions of Jaipur city of Rajasthan, India.

\section{Materials and Methods}

The current investigation was attempted to determine the predominance of Staphylococcus aureus as a developing food borne microbe considering its general wellbeing essentialness with the point of isolating and recognizing $S$. aureus from raw milk samples. The recouped isolates were confirmed based on their biochemical, morphological and cultural characteristics and further by Polymerase Chain Reaction (PCR) at species and genus level. Cultures identified as $S$. aureus were exposed to study for their properties corresponding to in vitro characterization for the presence of capsular polysaccharide (cap5 \& cap8) genes.

\section{Isolation of S. aureus from milk samples}

A sum of 790 raw milk samples were collected from 8 different regions of Jaipur city of Rajasthan, India. The samples were taken from street wanders and clinically healthy animals in sterile bottles. Initially samples were identified by conventional microbiological methods using phenotypic and biochemical characteristic. In this regard, the samples were poured onto Staphylococcus aureus specific chromogenic agar plates which contain polymyxin B (50 units $/ \mathrm{ml})$ (HiMedia Laboratories, India). After 24 hours of incubation at $37^{\circ} \mathrm{C}$, the colonies which produce greenish and bluish colour were transferred to a BHI broth medium. The color mixture in the center is specifically engraved by Staphylococcus aureus to produce bluishgreenish colonies, which can be seen clearly against a dark background. For the further confirmation the cultures were suspended on Baird Parker Agar and Mannitol Salt Agar Plates (Himedia Laboratories). Subsequently, 
colonies were examined for morphology after Gram staining and confirmed using the API staph kit group (bioMeriux, Marcy-l'Etoile, France). By tube plasma agglutination test clustered colonies confirmed for coagulation activity were tested.

\section{Genotypic confirmation of $S$. aureus (Ribotyping)}

The microbiologically confirmed cultures were allowed to grown overnight in incubator shaker in BHI broth and then DNA was isolated from these cultures individually by the method of Pospiech and Neumann (1995). DNA quantification was done by spectrophotometer (Sambrook et al., 1989) and then DNA was diluted to concentration of $25 \mathrm{ng} / \mu \mathrm{l}$ in TE buffer and ribotyping based on 23S rRNA gene was done (Straub et al 1999) using species specific primers i.e. (Primer-1) 5'-CGGAGTTACAAAGGACGAC-3' and (Primer-2) 5'-AGCTCAGCCTTAACGAG TAC-3'. A $25 \mu$ PCR cocktail was prepared which is composed of $12.5 \mu \mathrm{l}$ of $2 \mathrm{X}$ DreamTaq green PCR master mix (Thermo scientific, Mumbai, India), $0.5 \mu \mathrm{M}$ of each primer and $1 \mu \mathrm{l}$ of template DNA was prepared and performed in a thermocycler system (Agilent Technologies, New Delhi, India). The programme used for PCR cycles was: 2 min at $95^{\circ} \mathrm{C}$, followed by 35 cycles of $30 \mathrm{~s}$ at $95^{\circ} \mathrm{C}, 45 \mathrm{~s}$ at $57^{\circ} \mathrm{C}$ and $60 \mathrm{~s}$ at $72^{\circ} \mathrm{C}$ with a final extension of $10 \mathrm{~min}$ at $72^{\circ} \mathrm{C} .1 \mathrm{~kb}$ ladder (Thermo scientific, Mumbai, India) was used as marker on $1.2 \%$ agarose gel.

\section{Amplification of cap5 and cap8 genes}

For the amplification of cap5 and cap 8 genes the method of Verdier et al., (2007) was followed. The primers sequence were (Primer-1) 5'-GTCAAAGATTATGTGATG CTACTGAG-3' and (Primer-2) 5'-ACTTCG AATATAAACTTGAATCAATGTTATACA G-3'used for the amplification of cap5 gene and it were (Primer-1) 5'-GCCTTATGT TAGGTGATAAACC-3' and (Primer-2) 5'GGAAAAACACTATCATAGC AGG-3' used for the amplification of cap 8 gene. A 25 $\mu 1$ PCR cocktail was prepared as per quantity mention above. The programme used for cap5\&cap8gene PCR cycles was: $2 \mathrm{~min}$ at $95^{\circ} \mathrm{C}$, followed by 35 cycles of 30 s at $94^{\circ} \mathrm{C}$ (denaturation), $50 \mathrm{~s}$ at $55^{\circ} \mathrm{C}$ (annealing) and $50 \mathrm{~s}$ at $72^{\circ} \mathrm{C}$ (elongation) with a final extension of $10 \mathrm{~min}$ at $72^{\circ} \mathrm{C}$. The PCR products, after addition of $2 \mu 1$ of trekking dye were resolved in $1.2 \%$ agarose gels prepared in $0.5 \times \mathrm{TBE}$ buffer containing $0.5 \mu \mathrm{g} / \mathrm{ml}$ of ethidium bromide. 100 bp DNA ladder (Thermo scientific, Mumbai, India) was used as marker. The amplified products were electrophoresed for 2 hours at $100 \mathrm{~V}$. After that the gel was visualized under Gel Documentation system (Bio-Rad, USA).

\section{Results and Discussion}

Here at initial level, $S$. aureus isolates were identified by conventional microbiological procedures using biochemical and phenotypic characteristics and then final confirmation was done by $23 \mathrm{~S}$ rRNA based ribotyping developed by Straub et al., (1999) for genotypic confirmation. The PCR products having amplicon size of 1250bpwere confirmed as $S$. aureus. In the present investigation, out of 790 milk samples isolated from different regions of Jaipur city, only 144 isolates were confirmed on molecular level. Out of these 144 confirmed samples 59 isolates shows positivity towards coagulase producing gene (coa gene) and these samples having coa gene were selected for this study (Data related to coa gene is not mentioned here). The same method of genotypic confirmation has been used by Yang et al., (2012); Parth et al., (2016); Hamid et al., (2017) and Choudhary et al., (2018). They obtained species-specific amplicon of 1250 bp which confirm 
genotypic identification of this organism. They did the same from milk samples of different geographical locations.

\section{Genes for antiphagocytosis (cap5 and cap8)}

The PCR products $361 \mathrm{bp}$ and $173 \mathrm{bp}$ confirm the presence of cap5 and cap 8 gene, respectively. A duplex PCR was carried out to detect both cap5 and cap 8 (capsular genes) in single PCR reaction and also to detect variability in capsular genes (cap5 and cap8) among $59 \mathrm{~S}$. aureus isolates. Out of 59 strains, 32 isolates $(54.24 \%)$ produced amplicon size of 361 bp confirming the presence of cap5 gene and 16 isolates (27.12\%) expressed presence of cap 8 gene with173 bp amplicon size (Table 1). Thus, the majority of the analyzed isolates were havingcap5genes with compared to cap 8 gene. Both genes were detected in 06 isolates $(10.17 \%)$. Variability in prevalence of capsular genes was observed in S. aureus isolates with respect to different places of sampling though cap5 genotype predominated almost in all the regions except Sodala region as displayed in the form of figure (Fig. 1 and 2).

Table.1 Distribution of the cap5 and cap 8 genes among S. aureus isolates obtained from different regions of Jaipur city

\begin{tabular}{|c|c|c|c|c|c|c|}
\hline \multirow[t]{2}{*}{ S. No } & \multirow{2}{*}{$\begin{array}{l}\text { Place of } \\
\text { sampling }\end{array}$} & \multirow{2}{*}{$\begin{array}{c}\text { No. of } \\
\text { samples }\end{array}$} & \multicolumn{4}{|c|}{ Total prevalence of capsular polysaccharides gene \% } \\
\hline & & & cap5 (361bp) & cap8 (173bp) & Both & NT \\
\hline 1. & Amer & 9 & $6(66.67 \%)$ & $1(11.11 \%)$ & $2(22.22 \%)$ & $0(0.00 \%)$ \\
\hline 2. & Bagru & 6 & $4(66.67 \%)$ & $2(33.33 \%)$ & $0(0.00 \%)$ & $0(0.00 \%)$ \\
\hline 3. & Durgapura & 8 & $3(37.50 \%)$ & $2(25.00 \%)$ & $1(12.50 \%)$ & $2(25.00 \%)$ \\
\hline 4. & Jhotwara & 5 & $3(60.00 \%)$ & $2(40.00 \%)$ & $0(0.00 \%)$ & $0(0.00 \%)$ \\
\hline 5. & Khatipura & 8 & $4(50.00 \%)$ & $2(25.00 \%)$ & $1(12.50 \%)$ & $1(12.50 \%)$ \\
\hline 6. & Mansarovar & 10 & $6(60.00 \%)$ & $3(30.00 \%)$ & $0(0.00 \%)$ & $1(10.00 \%)$ \\
\hline 7. & Sanganer & 6 & $3(50.00 \%)$ & $1(16.67 \%)$ & $2(33.33 \%)$ & $0(0.00 \%)$ \\
\hline 8. & Sodala & 7 & $3(42.86 \%)$ & $3(42.86 \%)$ & $0(0.00 \%)$ & $1(14.29 \%)$ \\
\hline & Total & 59 & $32(54.24 \%)$ & $16(27.12 \%)$ & $6(10.17 \%)$ & $5(8.47 \%)$ \\
\hline
\end{tabular}

Fig.1 Distribution of cap5\&cap8 gene (\%) in Staphylococcus aureus strains isolated from milk samples of various regions

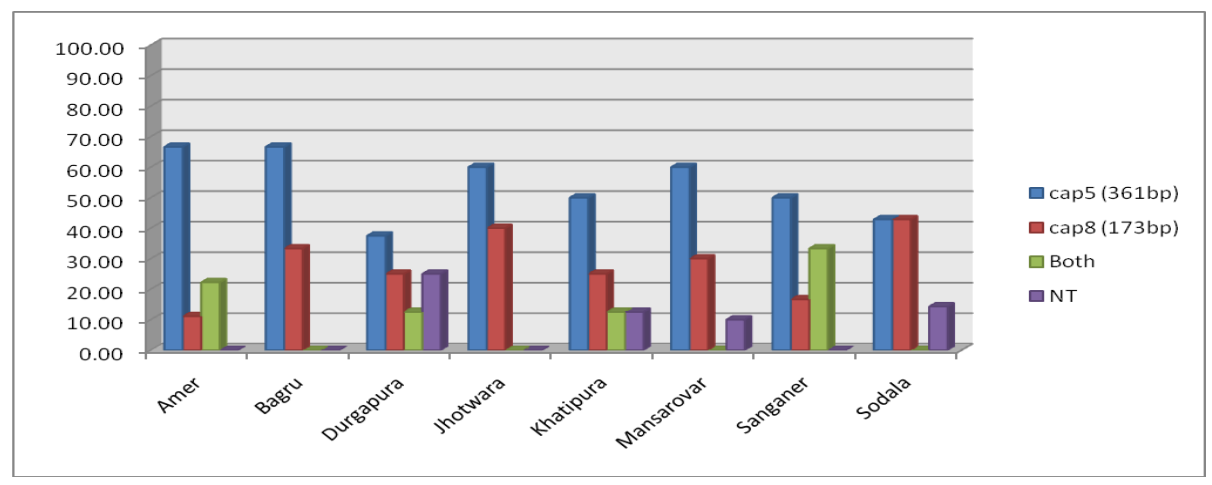


Fig.2 Agarose gel electrophoresis of thecap5\&cap 8 genes present in various strains of Staphylococcus aureus. M=Marker (100 bp ladder)

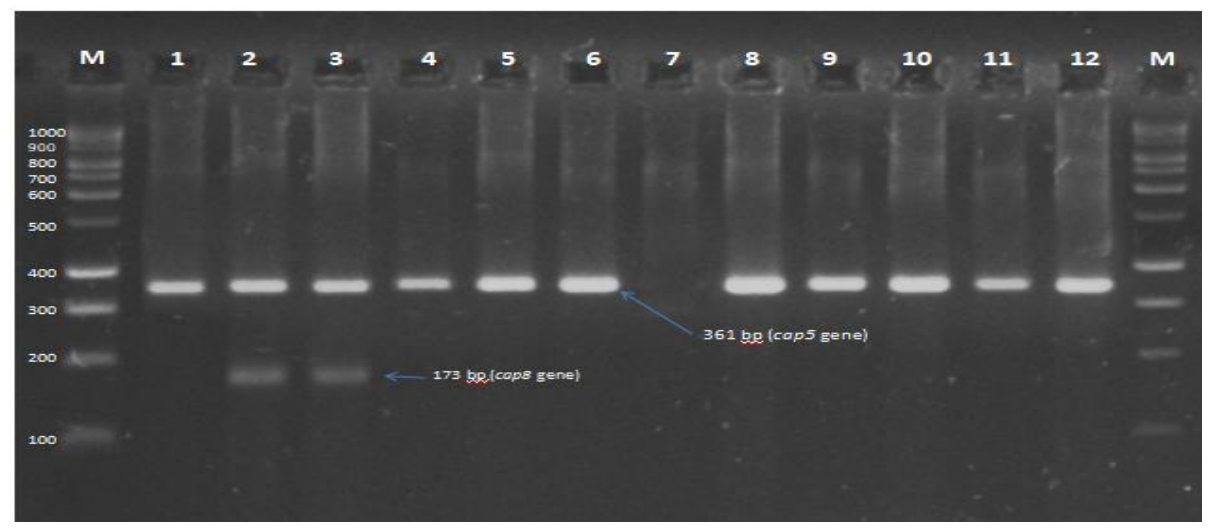

The present study support the previous studies reporting higher prevalence of cap5 gene (in comparison to cap8 gene) in $S$. aureus isolates from different sources viz. $60 \%$ cap 5 gene by Upadhyay et al., (2010).Similarly higher proportion of cap5 isolates has also been published from Indonesia by Salasia et al., (2004), Reinoso et al., (2008); Camussone et al., (2012) from Argentina; Salimena et al., (2016) from Brazil, Kumar et al., (2011) and Krithiga et al., (2018) from India. In a similar study observed by Reinoso et al., (2008), the higher percentage of cap5 genotype in human isolates (11out of 45) than bovine strains (09 out of 45). All bovine strains were negative with cap8 gene which is in dissimilar to present study.

Maximum prevalence (66.76\%) of cap5 gene was present in the stains of Amer and Bagru regions while lowest prevalence $(37.50 \%)$ was found in the strains of Durgapura region of Jaipur city. Further, prevalence of cap 8 gene was maximum found $(42.86 \%)$ in the strains of Sodala area which is surprisingly as similar as cap5 gene and it was lowest in the strains of Amer area (11.11\%). 25\% of the strains of Durgapura area were not typable. Actually such kinds of studies was not done previously in these particular regions so here we can only analyze the same data in cumulative manner with others studies.
In contrary to present study, Tollersrud et al., (2000) reported a greater variation in the distribution of capsular serotypes among isolates from cows of various geographical regions and reported a higher proportion of cap8 than cap5 gene. Salasia et al., (2004) observed that majority of the strains (12 out of 19) isolated in Hesse, Germany harboured the gene cap8 while Ikawaty et al., (2010) detected cap 8 in 73 isolates and cap 5 in three isolates from Netherlands. Some workers didn't record any of the isolates harbouringcap8 gene (Proietti et al., 2010) or carrying cap5 gene (Soares et al., 2017). Nontypable strains as observed in this study were also reported by Upadhyay et al., (2010); Yadav et al., (2015) from the same laboratory and locations. Contrary to the above findings very low (14\%) percentage of cap5 and cap8S. aureus isolates were detected by Sordelli et al., (2000) as 7.10\% serotype 5 and $6.60 \%$ serotype 8 and very high percentage $(86.20 \%)$ of non-typable isolates by serotyping.

In conclusion the overall, outcome of this study revealed that bovine raw milk samples collected from the various regions of Jaipur city of Rajasthan were contaminated with $S$. aureus. By PCR based method, all the isolates were typed by targeting specific genes (cap5\&cap8) with the predominance of 
cap5gene.This study will be helpful to obtain a better knowledge on the distribution of capsular polysaccharides among Staphylococcus aureus present in milk samples of various regions of Jaipur, the capital of Rajasthan and might be helpful to formulate future strategies to control the bacterial contamination in milk.

\section{References}

Camussone, C., Rejf, P., Pujato, N., Schwab, A., Marcipar, I. and Calvinho, L. F. 2012. Genotypic and phenotypic detection of capsular polysaccharides in Staphylococcus aureus isolated from bovine intramammary infections in Argentina. Brazilian Journal of Microbiology. 43:1010-1014.

Choudhary, S., Diwakar, Bhati, T. and Kataria, A. K. 2018. Molecular typing of virulence associated gene (spa) of $S$. aureus isolated from cattle clinical mastitis. Journal of Entomology and

Hamid, S., Bhat, M.A., Mir I. A., Taku A., Badroo G.A., Nazki S., and Malik A. 2017. Phenotypic and genotypic characterization of methicillin-resistant Staphylococcus aureus from bovine mastitis, Veterinary World, 10(3): 363-367.

Ikawaty, R., Brouwer, E.C., Duijkeren, V.E, Mevius, D., Verhoef, J. and Fluet, A.C. 2010. Virulence factors of genotyped bovine mastitis Staphylococcus aureus isolates in the Netherlands. International Journal of Dairy Science. 5 (2): 60-70.

Khichar, V. and Kataria A. K. 2014. Capsular genotyping (cap5k and cap $8 \mathrm{k}$ ) of Staphylococcus aureus isolates from cattle with clinical mastitis. Human and Veterinary Medicine International Journal of Bioflux Society. 6 (1): 30 -33.

Krithiga, N., Antony, P. X., Tollersrud, T., Mukhopadhyay, H. K., Pillai, R. M., Vijayalakshmi, P. and Thanislass, J. 2018. Molecular typing of capsular polysaccharides of Staphylococcus aureus isolated from cases of bovine mastitis by PCR. Concepts of Dairy and Veterinary Sciences.1(1)-.CDVS.MS.ID.000102.

Kumar, R., Yadav, B. R. and Singh, R. S. 2011.
Antibiotic resistance and pathogenicity factors in Staphylococcus aureus isolated from mastiticSahiwal cattle. Journal of Bioscience. 36 (1):175-188.

Normanno, G., Firinu A., Virgilio S., Mula G., Dambrosio A., Poggiu A., Decastelli L., Mioni R., Scuota S., Bolzoni G., Di Giannatale E., Salinetti A. P., La Salandra G., Batoli M., Zuccon F., Pirino T., Sias S., Parisi A., Quaglia N. C., Celano G.V. 2005. Coagulase-positive staphylococci and Staphylococcus aureus in food products marketed in Italy. Int $\mathbf{J}$ Food Microbiol 98:73-79.

Parth, F.M., Chauhan, H. C., Bhagat, A. G., Chandel, B. S., Patel, M. V., Dadawala, I. and Kher, H. N. 2016. Detection of virulence associated factors from Staphylococcus aureus isolated from bovine mastitis. Buffalo Bulletin.35 (4):687-696.

Pospiech A, Neumann B: A versatile quick-prep of genomic DNA from gram-positive bacteria. Trends Genet 1995, 11(6):217218.

Proietti, P.C., Coppola, G., Bietta, A., Marenzoni, M.L, Hyatt, D.R., Coletti, M. and Passamonti, F. 2010.Characterization of genes encoding virulence determinants and toxins in Staphylococcus aureus from bovine milk in Central Italy. Journal of Veterinary Medical Science.72 (11):14431448.

Reinoso, E. B., El-Sayed, A., Lämmler, C., Bogni, C. and Zschöck, M. 2008. Genotyping of Staphylococcus aureus isolated from humans, bovine subclinical mastitis and food samples in Argentina. Microbiological Research.163 (3):314-322.

Salasia, S. I. O., Khusnan, Z., Lammler, C. and Zschock, M. 2004. Comparative studies on phenotypic and genotypic properties of Staphylococcus aureus isolated from bovine subclinical mastitis in central Java in Indonesia and Hesse in Germany. Journal of Veterinary Science. 5 (2):103109.

Salimena, A. P., Lange, C. C., Camussone, C., Signorini, M., Calvinho, L. F., Brito, M. A., Borges, C. A., Guimarães, A. S., Ribeiro, J. B., Mendonça, L. C. and Piccoli, R. H. 
2016. Genotypic and phenotypic detection of capsular polysaccharide and biofilm formation in Staphylococcus aureus isolated from bovine milk collected from Brazilian dairy farms. Veterinary Research Communications. 40(3-4):97-106.

Sambrook, J., Fritsch, E.F. and Maniatis, T. 1989. Purification of DNA.In: Molecular cloning: A Laboratory Manual. $2^{\text {nd }}$ edn.Cold-Spring Harbor Laboratory, Cold-Spring Harbor, New York.

Soares, B. S., Melo, D. A., Motta, C. C., Marques, V. F., Barreto, N. B., Coelho, S. M. O., Coelho, I. S. and Souza, M. M. S. 2017. Characterization of virulence and antibiotic profile and agr typing of Staphylococcus aureus from milk of subclinical mastitis bovine in State of Rio de Janeiro. Arquivo Brasileiro de Medicina Veterinária e Zootecnia.69 (4):843-850.

Soomro, A.H., Arain, M.A., Khaskheli, M., Bhutto, B. Isolation of Staphylococcus aureus from milk products sold at sweet meat shops of Hyderabad. Online J. Biol. Sci.,k 2003, 3(1): 91-94.

Sordelli, D. O., Buzzola, F. R., Gomez, M. I., Steele-Moore, L., Berg, D., Gentilini, E., Catalano, M., Reitz, A. J., Tollersrud, T., Denamiel, G., Jeric, P., Lee, J.C. 2000. Capsule expression by bovine isolates of Staphylococcus aureus from Argentina: genetic and epidemiologic analyses. Journal of Clinical Microbiology. 38(2): 846-50.

Straub, J. A., Hertel, C. and Hammes, W. P. 1999. A 23S rRNA target polymerase chain reaction based system for detection of
Staphylococcus aureus in meat starter cultures and dairy products. Journal of Food Protection.62 (10): 1150-1156.

Tollersrud, T., Kenny, K., Reitz, A. J. Jr. and Lee, J. C. 2000. Genetic and serologic evaluation of capsule production by bovine mammary isolates of Staphylococcus aureus and other Staphylococcus spp. from Europe and the United States. Journal of Clinical Microbiology.38 (8): 2998-3003.

Upadhyay, A., Kataria, A. K., Sharma, R. and Singh, G. 2010 Capsular typing of Staphylococcus aureus isolates from cattle and goat mastitis by PCR targeting cap $5 \mathrm{~K}$ and cap $8 \mathrm{~K}$ genes. Indian Journal of Animal Science.80 (11):1062-1065.

Verdier, I., Durand, G., Bes, M., Taylor, K. L., Lina, G., Vandenesch, F., Fattom, A. and Etienne, J. 2007. Identification of the capsular polysaccharides in in Staphylococcus aureus clinical isolates by PCR and agglutination tests. Journal of Clinical Microbiology.45 (3):725-729.

Yadav, R., Sharma, S. K., Yadav, J., Nathawat, P. and Kataria, A. K. 2015.Phenotypic and genotypic characterization of Staphylococcus aureus of mastitic milk origin from cattle and buffalo for some virulence properties. Journal of Pure and Applied Microbiology. 9 (1): 425-431.

Yang, F. L., Li, X. S., Liang, X. W., Zhang, X. F., Qin, G. S. and Yang, B. Z. 2012. Detection of virulence-associated genes in Staphylococcus aureus isolated from bovine clinical mastitis milk samples in Guangxi. Tropical Animal Health and Production. 44 (8): 1821-1826.

\section{How to cite this article:}

Khan, A., R. Sharma, R. Grover and Rizwan, M. 2020. Capsular Typing of Staphylococcus aureus Isolated from Raw Milk Samples using Duplex Polymerase Chain Reaction. Int.J.Curr.Microbiol.App.Sci. 9(11): 2044-2050. doi: https://doi.org/10.20546/ijcmas.2020.911.243 